\title{
Working Together: Understanding Value Co-Creation Processes in Professional Service Delivery
}

\author{
Liudmila Bagdoniene, Gintare Valkauskiene
}

Kaunas University of Technology

K. Donelaicio st. 73, LT-44029, Kaunas, Lithuania

E-mail.liudmila.bagdoniene@ktu.lt,gintare.valkauskiene@ktu.edu

cross $^{\text {ref }}$ http://dx.doi.org/10.5755/j01.ee.29.1.18436

Creating superior client value is key to company success. Traditionally, research on value creation has focused on the value created by the company, though the client increasingly serves as an active partner, able to create value within the company in a collaborative manner. This is especially true for professional services that require more collaborative development of business solutions and a greater client adoption. The authors focus on a specific type of professional services - business consulting - and aim to characterize the value co-creation processes that occur between a business consulting company and its clients. The case study results reveal eight value co-creation processes with different impacts on a service provider and a client: (1) building trust and trusting relationships; (2) clients' needs identification; (3) clarifying the client's role; (4) self-motivation to be involved in value co-creation; (5) pursuit of service effectivenes; (6) involvement and commitment for mutual long-term activities; (7) identification of opportunities for reciprocal cooperation, and (8) searching the conditions for mutual growth. Value co-creation processes are analysed from a client perspective.

Keywords: Value Co-Creation; Processes; Provider; Client; Professional Services; Case Study.

\section{Introduction}

In a modern economy, business companies have to continuously reinvent themselves in order to adapt to the complex and dynamic business environment. New forms of interaction are superseding the conventional point of view on exchange of information. Regarding this point of view, the involvement of the client in value co-creation is considered and featured as a prerequisite for becoming and remaining competitive (Saarijarvi et al., 2013; Schertzer et al., 2013). From the value co-creation perspective, service providers and clients are no longer on opposite sides; they interact reciprocally for the development of new services, products and solutions, as well as new business opportunities. This means the mode by which value is created, distributed, paid for and exploited differs significantly from the traditional demand vs supply model (Galvagno \& Dalli, 2014).

Business-to-business (B2B) professional services have been recently recognized as rapidly growing (Madhavaram \& Hunt, 2017) and one of the most profitable sectors in the global economy (Empson et al., 2015). Professional services, despite the wide range of diversity (see NACE Rev. 2 division 69-74), are characterized by high knowledge intensity, flexible knowledge-intensive processes, a professionalized workforce, a high degree of ongoing interaction and interpersonal communication, organizational and personal relationships, and service customization (Patterson \& Patterson, 2016; Fischer et al., 2014; von Nordenflycht, 2010; Dawson, 2012). These features are inherent for a professional service firms' (PSF) ability to tackle clients' unstructured problems. Mostly, these problems are solved by experts who posses distinctive competences in a particular field and involve joint continuous interaction between a service provider and a client. During the common problem solving process, service providers should define, disclose, offer and communicate the uniqueness in their value propositions (e.g., available experts, methodologies, references) (Lombardo \& Cabiddu, 2017) and be able to develop the provider-client relationships through continuous interaction and open dialog (Payne et al., 2008). All of this implies that the professional service is the particular context for value co-creation. There are studies that focus on topics important in the sense of value co-creation in the professional service context. Rennie et al. (2010), Nikolova et al. (2015) investigated the trust and trust building practices in professional services; Seiders et al. (2015) studied client motivation following expert advice; Taminiau et al. (2016) inquired about client relationship development; Omachonu et al. (2016) examined service quality; Neghina et al. (2017) examined the clients' motives and willingness to co-create, etc. At the same time, the processes of value co-creation are seldom empirically studied (Aarikka-Stenroos \& Jaakkola, 2012; Payne et al., 2008) despite that fact the value of the service is embedded in the processes and interactions between the company and the client over a period of time $(\mathrm{Ng}$ et al., 2010). Thus, the researchers should untangle, dissect and understand the processes through which service providers and clients co-create the value (Lombardo \& Cabiddu, 2017). This knowledge could help improve collaborations with clients in B2B environments and enhance the value of new service offerings (Jouny-Rivier et al., 2017).

The purpose of this study is to characterize the value co-creation processes between business consulting and 
couching companies as professional service providers and their clients. The value co-creation processes are analyzed from a client perspective.

The paper is organized as follows; firstly, the literature review on the value co-creation and professional services is presented. Secondly, the research method and context of the study are discussed. Thirdly, the main findings are presented followed by a discussion and concluded with research limitations and future avenues for research.

\section{Defining Value Co-Creation Processes in the Professional Services}

Value co-creation is a business paradigm describing how customers could be involved as active actors in the design and development of personalized products, services and experiences (Prahalad \& Ramaswamy, 2004) through resource integration. The resources can differ in terms of quality and quantity, and require complementarities (Gummesson \& Mele, 2010). The provider tailors professional skills, methods and solutions, whereas the client contributes knowledge and other resources (Aarikka-Stenroos \& Jaakkola, 2012). Co-creation as a joint, collaborative, peer-like process produces new value (Galvagno \& Dalli, 2014), which has different meanings for customers and for practitioners (Gallarza \& Saura, 2006). This means value is contextual, subjective and idiosyncratic in nature (Bharti et al., 2014; Stenroos \& Jaakkola, 2010). Value can be defined as some form of assessment of benefits against sacrifices, means-end models or appreciation of the object of consumption (Gronroos, 2011), and can also be treated as monetary gains created mutually and reciprocally by business partners (Gronroos \& Helle, 2010). Value can therefore be characterized by a variety of dimensions (forms). It can be utilitarian and hedonic; extrinsic, intrinsic and systemic; functional, social, emotional, epistemic, conditional (Sanchez-Fernandez \& Iniesta-Bonillo, 2007; Piligrimiene et al., 2015). Considering that service companies cannot deliver value but only offer a value proposition; gaining an understanding of the co-creation processes and its procedures, tasks, mechanisms, activities and interactions becomes critical (Trischler et al., 2017; Payne et al., 2008). Table 1 presents several scholarly views on value cocreation processes.

Table 1

Value Co-Creation Processes

\begin{tabular}{|c|c|}
\hline Author (-s) & The processes of value co-creation \\
\hline \multirow[t]{3}{*}{ Sjodin et al. (2016) } & 1. Requirement definition \\
\hline & 2. Customization and integration \\
\hline & 3. Implementation and operation \\
\hline \multirow{3}{*}{$\begin{array}{l}\text { Gronroos \& Voima } \\
\text { (2013) }\end{array}$} & 1. Value co-creation processes by customers \\
\hline & 2. Value co-creation processes by providers \\
\hline & $\begin{array}{l}\text { 3. Value co-creation processes by joint } \\
\text { provider and customer attempts }\end{array}$ \\
\hline \multirow[t]{3}{*}{ Payne et al. (2008) } & 1. Customer value creating processes \\
\hline & 2. Provider value creating processes \\
\hline & 3. Encounter processes \\
\hline
\end{tabular}

Sjodin et al. (2016) describes three broad types of value co-creation processes. First, the requirement definition involves jointly considering customer needs that may not be known or expressed clearly, and then creating a joint understanding of a customer's broader operational needs. Second, conjoint designing, modifying, or selecting service solutions to fit into the overall operating environment, as well as defining contractual agreements are treated as the customization and integration processes. Third, implementation and operation comprise of delivering and installing the solutions, participating in the start-up, and working in the operational environment. Gronroos and Voima (2013) reveal three types of value cocreation processes, named as the customers' sphere, providers' sphere and joint sphere. The customer sphere is determined as an experiential sphere outside direct interactions where value-in-use (real value) emerges (cocreated) through the customer's accumulating experiences with resources and processes in social, physical, temporal and spatial contexts. The provider sphere is outlined as a providers dominant sphere outside direct interactions, where activities performed by the provider result in the production of resources and processes that the customer may use in their value creation process. Joint sphere is a sphere where the customer is responsible for value creation, but through the dialogical process of direct interactions when the provider may get the opportunity to influence the customer's value creation process as a value co-creator (Gronroos \& Voima, 2013). Value co-creation, described by Payne et al. (2008), involves three key processes: customer-driven, provider-driven and encounter processes. Customer's value creation processes are oriented to achieve particular objectives. These processes should be viewed as dynamic, interactive, non-linear and often unconscious. The provider's processes start from the comprehension of the customer's value creating processes and involve a review of co-creation possibilities, planning, testing and prototyping value co-creation opportunities with customers, implementing customer solutions and managing the customer encounter. By starting with the customer processes, a provider designs their own processes with the customer's processes. The encounter processes include the two-way interactions and transactions between the service provider and customer. These encounters can be viewed as exchange performances, in which parties integrate resources, e.g. money, products, work, information, time, etc., and collaborative practices.

The most recent streams of research on value cocreation have shifted toward specific industries, such as education, healthcare, hospitality and professional services. The changes in the professional services industry require a more iterative and collaborative development to produce solutions that are more creative and produce a greater client adoption. Professional service firms serving a variety of clients need to understand the differences in the joint value creation process, depending on the type of client they are dealing with (Baumann et al., 2017). Thus, professional services should be designed to meet client needs (Sonmez \& Moorhouse, 2010; Zwass, 2010) and help clients to know more, to make better decisions, to have greater capabilities (Dawson, 2012), increase the effectiveness of organizational functions or/and higher profitability (Kukk \& Leppiman, 2016; Urbonavicius \& Dikcius, 2005). Customizing professional services is a knowledge intensive process that requires coordinated efforts of individuals, with specialized knowledge and 
skills (Madhavaram \& Hunt, 2017; Zieba \& Zieba, 2014). Non-routine problem solving is possible, due to the high degree of professional expertise and individual judgement (Hogan et al., 2011; Lowendahl, 2005), in addition to effective interaction between professionals (consultants) and customers (Nikolova et al., 2009; Lombardo, 2014). Interaction supported by relational competence (Kaiser \& Ringlstetter, 2011) serves as a learning-experience exchange platform and creates an opportunity to develop interpersonal social relations. Trust is another interaction driver, consisting of the benevolence, honesty and competence, which are viewed as an important source of value in professional service relationships (Howden \& Pressey, 2008). It acts as a lens through which the actions of a trusted individual are interpreted (Rennie et al., 2010). A client's interest to be involved in value co-creation is dependent on diverse motivational factors. According to Hoyer et al. (2010), these factors may be financial, social, technical, psychological, etc. In value co-creation, interaction, trust and motivation are significant factors, because in professional services the client evaluates the value of service based not only on the outcome but also on the process (Kukk \& Leppiman, 2016). On the other hand, the relationships between a professional service firm and client are influenced by information asymmetry, which may become a challenge for co-creation (Kukk et al., 2015). It complicates not only interaction between client and service provider, and also information sharing. In order to solve the customer's business problem effectively, the professional service firm has to make sure that the client is aware of how their problem is going to be tackled and what their contribution has to be (Kukk et al., 2015). Professional service firms should control information asymmetry (Antonova, 2012) and pursue an open and transparent client relationship.

\section{Research Method and Context}

The value co-creation processes between a professional service provider and its clients using qualitative methodology was chosen, due to this area of research being a less-studied topic. Qualitative research is the correct methodology in a situation when the researcher wants to study a new or less-investigated topic in depth (e.g. in one organization), to understand the context within which decisions and actions take place, to uncover the perspectives of study participants and to interpret the reality through social meanings (Myers, 2013; Eriksson \& Kovalainen, 2015). The qualitative methodology comprises of different research strategies. The authors have prioritized the case study considering its particular qualities that correspond to the research. Firstly, the case study allowed an in depth examination of a problem in a practical (real life) situation and gain a profound insight into the processes that are confined in time and space. Second, it permits investigation in a small number of units (sometimes one), which could be an organization. Third, a case study helps find instances of good practice within an organization (Farguhar, 2012; Verschuren \& Doorewaard, 2010). Therefore, the aim is not to make statements about the cases to a larger population but to explore in depth the value co-creation processes as a particular phenomenon and in the delivery of professional services as a specific context. As mentioned earlier, the professional service firm sector contains a host of different subsectors; therefore the context of the study chosen is the business consulting and couching services. Consulting is an iterative process with the objective of influencing the behavior of clients during a problem solution and supporting clients with its implementation. Client involvement in consulting services and active participation in co-creation of a business problem solution is more critical than in other professional services (Kaiser \& Ringlstetter, 2011).

The selection of research participants for qualitative studies is purposeful rather than representative and random, unlike the quantitative research (Eriksson \& Kovalainen, 2015). Thus, the participants were chosen using purposive sampling (Teddlie \& Yu, 2007) due to the qualities the participants possess (the knowledge and experience). A professional service provider was selected as a regional business consulting and couching company (hereafter $\mathrm{BCC}$ ), providing services to the business-tobusiness (B2B) market. BCC was selected as the research case for the following reasons; firstly, there is rapid growth in the company, as this company initially operated as a regional business training provider, however currently the company is known as a business consulting and couching provider in Lithuania, Latvia and Estonia. Secondly, the change of the company business orientation, where the focus from short-term service sales' was changed by philosophy and strategy to creating continuous relationships with clients. This shift in the company's activity is reflected in their modified mission statement "Inspire to improve" and vision statement "Constantly evolving man, organization and society" supported by three fundamental values - "sustainable partnership, inspired people and implemented goals - lead to a continuous relationships with clients". Consequently, BCC is presently deeply oriented towards initiating and implementing changes in clients' businesses through the value co-creation, by providing customized solutions for their businesses. Thirdly, the expansion of service offerings and the client's portfolio. Customized services in BCC's service portfolio currently compose the major part of their business and replace the standardized training services. These reasons demonstrate critical changes in BCC's collaboration practices with clients and support why BCC was chosen as the research case, in addition to becoming the principal argument why the co-creation of value between this company and their clients was selected for this case study.

Empirical data was collected during March-April 2016. During this period, BCC pursued four businessconsulting projects. Three of the four client companies met the defined client company's selection criteria: 1) position in the market (all three companies are leading companies in their business market); 2) duration of collaboration (these client companies have collaborated with BCC for more than 4 years) and 3) clients' market type (all three client companies operate in business-to-business (B2B) markets. The researchers, interceded by BCC's owner, personally met with top managers of all three companies and invited their companies to participate in the research. However, one company rejected the invitation, arguing that 
they cannot provide any information about collaboration with partners, including BCC. Thus, two BCC client companies, named $\mathrm{A}$ and $\mathrm{B}$ (the real titles of these firms were not announced according to their request), were incorporated in the research.

Company A has roots in heavy equipment manufacturing that date back to 1966 and has combined experience with contemporary technologies, therefore today is able to provide customers with the most innovative and most professional solutions. Company A operates in the entire Baltic and Nordic markets. In order to create the greatest possible value to the customer, company A continually invests in production, business management, customer service processes and long-term training programs.

Company B was founded in 1999 and is a fast-growing company that provides high quality indoor and outdoor area cleaning services. It also provides hygiene supplies and a dirt-collecting mat rental service. Cleaning work processes only use certified chemicals and tools, advanced technological equipment and machinery. This company currently employs more than 400 employees.

The data was triangulated by applying three data collection methods. Primarily, in order to better familiarize researchers with BCC clients. Secondary data was collected from these companies' websites. The primary data was gathered using two qualitative methods - a semi-structured interview and a focus group discussion. The interviews and focus group discussions were moderated by both researchers.

The semi-structured interviews were conducted with the Chief Executive Officer (CEOs) of both A and B companies. A guide for these semi-structured interviews was prepared based on the scientific literature analysis and composed by seven initial questions; concerning the value co-creation's aim, client's and provider's input, experience, practices that allows the co-creation processes, outcomes, benefit and insights in to future collaboration. Despite the predetermined questions, as the semistructured interview unfolds through conversation, it allows the participants to explore issues they feel are important (Longhurst, 2003). In this study, the semistructured interview was particularly useful for exploring the views of the BCC client firms' CEO towards experiences and benefits of value co-creation between $\mathrm{BCC}$ and their companies, as well as the vision of how value co-creation can be developed in the future. The interviews took place in the companies in which the participants worked. Each interview took around 45-50 minutes to complete, were recorded and after transcribed (the data comprised 13 pages of text).

The focus group discussions aim is to reveal different opinions and to collect data from individuals who have experienced some particular concrete situation (in the case of this research, the co-creation with $\mathrm{BCC}$ ). In addition, it allows observation of how and why discussion participants accept or reject others' ideas and develop their own questions (Krueger \& Casey, 2004; Liamputtong, 2011; Steward \& Shandasani, 2014). The discussions centered on the motivation to be involve in projects that require integration of personal and corporate resources, internal and external collaboration, the achievements of company and individuals, the experience and the possibilities of mutual development. Organizational culture, as a mediator for value co-creation between service provider and client, arose as an additional topic of the discussions.

In this case study, two focus groups were composed: eleven participants represent A company and twelve participants represent B company. The experience of participation in business problem solving co-creation projects was the main criteria for inviting employees to take part in the focus group discussion. Before the agreement to attend in the discussion the participants were informed of the research aim and were assured that information confidentiality would be guaranteed. The discussions were conducted carefully, explaining and clarifying some of the questions; as well as adding questions to follow up on interesting ideas and to direct the questions toward various topics. These discussions proceeded for more than 1 hour (75 min with A group and 80 min with B group). With the permission of participants, the discussions of focus groups were recorded and after every discussion were transcribed (the data comprised 39 pages of text). Due to the friendly atmosphere and wellmotivated participants, these conversations expressed a wide range of employees' experiences during co-creation projects with $\mathrm{BCC}$, feasible aims, benefits, and the possibilities to develop value co-creation in new projects.

The data obtained through semi-structured interviews and focus group discussions was analyzed using qualitative content analysis. To get the knowledge and understanding of the value co-creation between BCC and its clients, a directed approach to qualitative content analysis was chosen (Hsieh \& Shannon, 2005). In the first stage, codes were developed from the interview/focus group discussion data using the literature review as a theoretical basis. In the second stage, each interview/focus group discussion was coded and in the third stage, analysis and interpretation of the coding results, comparing the dialogue between theoretical and empirical material (Kvale, 2009).

\section{Main Findings}

Eight types of value co-creation processes that originate during collaboration between BCC and its clients' companies were identified (Table 2). As can be seen, value co-creation processes are allocated to one of three groups divided by the active agent: 1) processes performed by service provider, 2) processes conducted by client, and 3 ) processes executed by service provider and client together.

Table 2

Value Co-Creation Processes, Identified in Studied Case

\begin{tabular}{|c|c|}
\hline $\begin{array}{l}\text { The group of value } \\
\text { co-creation processes }\end{array}$ & Value co-creation processes \\
\hline $\begin{array}{l}\text { Value co-creation } \\
\text { processes performed } \\
\text { by service provider }\end{array}$ & $\begin{array}{l}\text { - building trust and trusting relationships; } \\
\text { - client needs identification for offering } \\
\text { relevant solutions; } \\
\text { - clarifying the client's role; }\end{array}$ \\
\hline $\begin{array}{l}\text { Value co-creation } \\
\text { processes conducted } \\
\text { by client }\end{array}$ & $\begin{array}{l}\text { - self motivating be involved in value co- } \\
\text { creation with BCC; } \\
\text { - pursuit of service effectiveness; }\end{array}$ \\
\hline $\begin{array}{l}\text { Value co-creation } \\
\text { processes as joint } \\
\text { service provider and } \\
\text { client attempts }\end{array}$ & $\begin{array}{l}\text { - involvement and commitment for mutual } \\
\text { long-term activities; } \\
\text { - identification of opportunities for two-way } \\
\text { development of cooperation; } \\
\text { - creation of conditions for mutual growth; }\end{array}$ \\
\hline
\end{tabular}


Value Co-Creation Processes Performed by Service Provider

The service provider operates as a facilitator of the value co-creation processes. Three processes that assist the value co-creation were identified: 1) building trust and trusting relationships, 2) client needs identification for offering relevant solutions, and 3) clarifying the clients' roles. According to the questioned CEO's, the value cocreation is inspired due to BCC employees' professionalism:

$<.$. the main value is that you [BCC] know your clients, you understand their business and know what they need... (Informant A);

$<$... you identify the weaknesses of our company and drew up a training scheme to eliminate them...> (Informant B).

Precise and prompt identification of a client's needs followed by offering tailored services cannot be without a high degree of trust. It is the cornerstone of a clients' willingness to cooperate, as well as to fulfil their roles share data, discuss the offered service concept, etc. Thus, trust is vital for building a trusting relationship:

$<$... your company [BCC] unlike other consulting firms that we have had on some other contracts concentrate on every participant of the training project - you ask what are our expectations, what we like or dislike...the main focus is of you not the business contract...we trust one another and that creates the open dialogue > (Focus group 1).

BCC offers the client innovative business solutions and insights into market trends that can influence the client's business competitiveness. Both CEOs stated that with BCC as a team of experts, their firms expect to find new ways to improve the business:

$<\ldots$ we need your [BCC] professionals to present certain solutions to our company, something the company itself cannot see...> (Informant A);

$<.$. we would like to receive new insights, new solutions, new training programs...> (Informant B).

Responsible attitude towards client's specific needs, finding out relevant troubles and proposing adequate services was accentuate during focus group discussions also:

$<\ldots$ BCC prepares the offerings specifically for our company... $>$ (Focus group 1);

$<\ldots$ during the service project we analyze the real and challenging issues for our company <...> BCC offers ideas how these problems can be solved or helps solve it. Everything is concrete. This makes it easier to find answers...> (Focus group 2).

The value co-creation processes of searching how to reveal and implement new business ideas, how to anticipate possible mistakes and misguided decisions, as noted by $\mathrm{A}$ and $\mathrm{B}$ companies CEOs, is possible due to BCCs' professional expertise and its rich experience achieved by working with different organizations:

$<.$. for us it is an important an opportunity to use your [BCC] experience gained while working with other companies... sharing good and bad cases... (Informant A); $<\ldots$ you [BCC] share with our company best practices...> (Informant B).

The trust, the competence and true partnership encourages the business progress. These factors were noted as the main reasons to continue collaboration with $\mathrm{BCC}$. According to the CEO's, the projects with $\mathrm{BCC}$, during which value co-creation is nurturing, assumes a new sense over time:

$<\ldots$ we participate in all processes and we feel involved... from needs identification to feedback...> (Informant A);

$<\ldots$ our involvement has changed. In the beginning of the collaboration, we only worked with some BCC departments, more exactly, with some employees. Now we have moved on to the next level - now our cooperation is closer...> (Informant B).

\section{Value Co-Creation Processes Conducted by Client}

As part of the client conducted value co-creation process, the investigation determined two processes: 1) self-motivation of being involved in value co-creation with $\mathrm{BCC}$ and 2) pursuit of service effectiveness.

Creating superior client value is a key to service provider success and the results of research support this fact. The collaboration with BCC stimulates client companies' staff to become more active and advance. The cooperation atmosphere, as well as the trust built by BCC, encourages the clients to discuss in an easy and informal manner as to what training is required to eliminate the present gap of knowledge and how to acquire the competence needed to meet the challenges of the business:

$<\ldots$ our people initiate training needs, suggest topics and are active and involved in competence development projects...> (Informant $\mathrm{A})$;

$<\ldots$ it is important to give employees personal freedom and responsibility to strengthen their competencies. It helps to train active and intelligent employees ...> (Informant B);

$<\ldots$ many of us participated in the project, whose aim was to create a motivation system. Everyone understood how important an effective motivation system is. Our interest in this project success helps BCC to organize a few very dynamic and fruitful sessions ...> (Focus group 2).

In addition, the commitment for value co-creation is a significant factor that promotes the effectiveness of the delivered services:

$<\ldots$ advantageous training is a stimulus to work better and more productive ...our services that we provide for our clients become better - it is clients'view...> (Focus group 1).

$<\ldots$ our new acquired competencies allow us with deeper empathy to feel our client's needs and expectations and react on them ...> (Informant $\mathrm{A}$ ).

In other words, value co-creation processes supported by $\mathrm{BCC}$ as a service provider strengthen the client company employees' self-motivation to develop a professional personality, whist acquiring new knowledge and experience. As a consequence, employees of the studied A and B companies are able to collaborate 
fruitfully with BCC when solving business problems. In this situation, BCC staff gain the knowledge and skills, which are resources used for the creation of business solutions. Thus, mutual value is created.

The success of value co-creation processes' heavily depends on the degree to which a company is able to build an organizational culture that is beneficial to cooperation for co-creating the value. Therefore, the management is responsible for reinforcing the co-creative mindset and skills of professionals, fostering internal and external collaboration, and nurturing co-creation initiatives:

$<$...if the managers initiate new projects, there needs to be co-creation with collaborators, they primarily should consult with employees who will be involved in these projects, explain the time costs, how the workload will be modified... Co-creation is time consuming... we cannot work at full capacity in our workplace and at the same time cooperate with collaborates...> (Focus group 2).

Value Co-Creation Processes as Joint BCC and Clients Attempts

Value co-creation arises during the formation and implementation of business strategies, service development or staff training projects; when companies find out the potential possibilities for their business growth:

$<$... immense value when the partner [BCC] understands and considers not only "here and now" but also sees where the company that is implementing the strategy is going and what is necessary to realize that strategy ...> (Informant A);

$<\ldots$ the participation of your [BCC] company in our business strategy development and implementation are the main benefit which allows us growth...> (Informant B).

Above-mentioned projects are long term, thus the results of value co-creation cannot be viewable in a short period:

$<\ldots$ at least one year (sometimes two or more years) is needed for perceiving and evaluating the results of our collaboration projects (for example, how the corporate learning culture changed) ...> (Informant A).

BCC's contribution to the recognition of the clients' business growth opportunities is based on understanding who the company's clients are and how their needs can be satisfied:

$<\ldots$ BCC knows our key clients, their products and markets...we discuss our business strategy outlines with knowledgeable people... every time BCC is prepared "homework" ...> (Focus group 2).

Value co-creation is deeper and more useful when $\mathrm{BCC}$ and the client companies are involved in integrated service projects or continuous service improvement projects:

$<$...continuous of our service development projects or training programs is very important. In this case, BCC and we (client company) can discuss the problems in a more detailed way... we create new knowledge and mutual experience...> (Focus group 1$)$.

Value co-creation causes reciprocal benefits that lead to mutual growth: $<\ldots$ competence is developed by both parties: you [BCC] and us...> (Informant A);

$<$... two-way involvement is like the standard of our collaboration... you [BCC] and us both gain the bonus... we need you [BCC] as well as you need us... > (Informant B).

The participants underline the importance of reciprocal relationships and expect that $\mathrm{BCC}$ will continue improving competences, in this way ensuring the variety and high quality of provided services:

$<. .$. it is very important what competences you [BCC] will have $<. . .>$ which ones will be relevant to us, at what level...> (Informant A);

$<$... you [BCC] should actively follow market trends, develop your [BCC] competence that continues adding value for us ...> (Informant B).

Obviously, BCC expertise and capabilities to cooperate with clients are treated as obligatory prerequisites of business problem solving. At the same time, skillful problem solving should be supported by the client's input, i.e. integration of their resources (dissemination of information, experience):

$<$... our company's situation and problems anonymously should be presented as a business case in $B C C$ training projects... from BCC's experience of working with different firms you may bring different examples also. Sharing real business information for more realistic training is valuable and interesting. Therefore, we can and should be useful for each other...> (Focus group 1).

The participants are certain that both the service provider and the client should be interested in strengthening the abilities to co-create value.

The changes in the business environment and the growing importance for business success of talented employees stipulate long-term relationships between BCC and client companies:

$<.$. we aim to train our people to enable them to assess what is necessary to pursue a career ...> (Informant A);

$<. .$. the company commits that the employees should be willing to grow first as professionals...> (Informant B).

What kind of value is co-created according to the study's participants? Client companies were concerned with customized services and task-related, functional, cognitive values. It is demonstrated during common activities, professionalism and identification of client needs, as well as customizing their solutions. At the same time, for BCC as service provider, the benefit of value cocreation means deeper competencies and a richer experience; or in other words, the epistemic value that is fundamental of further collaboration and has a positive effect on BCC's image, reputation and influences financial results.

\section{Discussion}

The research sought to characterize the processes of value co-creation between a provider of a professional service and its clients. A business consulting and couching company was chosen as the professional service firm and two of its clients. Investigation has revealed eight value cocreation processes divided in three groups: (1) processes 
conducted by the service provider, (2) processes performed by the client and (3) processes conducted by the service provider and client together. Service provider processes were identified as (1) building trust and trusting relationships, (2) client needs identification for offering relevant solutions and (3) clarifying the client's role. Two processes were defined as the client-moderated processes: (1) client's employees' self-motivation at being involved in value co-creation with BCC and (2) pursuit of service. The following service provider and client joint processes were recognized (1) involvement and commitment for mutual long-term activities, (2) identification of opportunities for two-way development of cooperation and (3) creation of conditions for mutual growth. The investigation classified the identified value co-creation processes in three groups, which are similar to Gronroos and Voima (2013) and Payne et al. (2008) proposed classifications. The main distinction resides in the unveiled content of value cocreation processes that arose in providing a business consulting service as one type of professional services. Additionally, specific benefits and opportunities to improve value co-creation that emerged in each process were highlighted.

Service provider conducted processes demonstrate the provider's professionalism, influence on the client's trust, ensure service quality and create the opportunities for client learning. Thus, professionalism is an important resource, which helps to overcome the uncertainties among clients (Kipping, 2011). As pointed out in the research findings, the clients are interested in updating their knowledge, receiving useful information and being involved in collaboration for defining valuable business insights. Therefore, the higher the level of service provider's professionalism, the better value proposition may be offered to clients (Aarikka-Stenroos \& Jaakkola, 2012; Komulainen, 2014).

Success of value co-creation depends also on the service provider's abilities to identify clearly the needs of clients, as well as on clarifying client roles. These research results are in line with Sonmez and Moorhouse (2010) and Zwass (2010) findings. Service, even at its design stage, should be targeted at meeting the client's needs. The research results show that identification of the client needs requires not only the provider having knowledge and skills but also client involvement in the service delivery (supplying information, consideration, proposals, etc.). Active reciprocity between the service provider and the client creates the prerequisite for effective business problem solving, thus interaction between the provider and client is treated as a source of mutual value creation (Lombardo, 2014). Jouny-Rivier et al. (2017) emphasizes the importance of a company's interaction-centric capabilities for understanding of the new locus of value creation.

A client's self-motivation to become involved in value co-creation, which was identified in this study as a process conducted by the client, is a starting point for value cocreation in professional services (Hoyer et al., 2010). The findings show that a client's motivation to be involved in the rendering of professional services is determined by their business environment, which becomes more and more complicated. Therefore, the employees must develop their competence. These findings partially correspond with Kukk and Leppiman (2016) who note that using professional services is 'forced by challenges' on companies to improve effectiveness and efficiency.

The research findings show that clients' learning during the execution of different service provider and client projects is experiential, i.e. strongly oriented toward activities, simulation of a real work setting and learning by doing. Thus, experiential learning is a means of expanding the effectiveness of services provided by the client companies. Dawson (2012) argues that experiential learning is the best way for developing a client's capabilities. The greatest value is in developing "metacapabilities", which enable clients to continually improving their own capabilities.

Knowledge and relationships are at the heart of future business. Professional services based on highly specialized knowledge play a significant role in this future. These research findings show the clients want the best expertise applied to their situation. Gustafsson et al. (2017) noted that clients demand more integrated and holistic services. Thus, it is likely the clients will be interested in cooperation with professional service providers if they are ready to improve on a regular basis their knowledge and skills that are needed for client problem solving.

Co-creation implies a joint value creation through resource integration between the service provider and client. The service provider is the facilitator of value cocreation, therefore, the provider must deeply understand the clients' practices and how they combine resources (Gronroos \& Voima, 2013). In this research, the formation of a business strategy, employees couching programs and other projects are a demonstration of how the professional service provider and client co-create the value and gain mutual benefit. The client has a competent consulting service provider, who facilitates the basis for successful business development, and the service provider conceives the client's business direction. Business competition is shifting from focusing on internal efficiency to how to leverage external sources, thus, co-creation turns a client's efforts, knowledge and skills into the unique competitive advantages (Zhang \& Chen, 2008).

A service provider and client's joint effort in value cocreation stimulate mutual growth. As noted in Lush et al. (2007), the co-creation with the client inspires innovation. The best way to discover service innovation opportunities is to understand how clients define value and knowing the client's needs that can direct meaningful service innovation (Bettencourt, 2010). In the case study, the clients' business vision and long-term goals may become the source of ideas of what new services will be needed for the clients in the future. Learning is another factor influenced by mutual growth. As the clients become more knowledgeable, professional service providers should pay more attention to their competence development. The employees must keep pace with knowledge development in their fields and continually generate new knowledge by building on what they have learned, and applying the experience gained when working on customer projects (Dawson, 2012). Kaiser and Ringlstetter (2011) highlight the scope and level of competence has a direct impact on the professional service firm's success. 
As shown in the findings of the research, continuous collaboration facilitates the value co-creation and builds up reciprocal confidence. These findings correspond with Nikolova et al. (2015), Ko (2014). For this reason, a professional service firm has to find ways in ensuring that the client becomes more involved and consciously participates in the service provision and the perceived company contribution to value co-creation for their company.

\section{Concluding Remarks, Limitation and Future Research Lines}

Value co-creation reflects a shift toward fundamentally different concepts of the nature of a business and value in professional services (Dawson, 2012). The modern client is increasingly informed, connected, knowledgeable, networked and empowered, and co-creation is a domain that indicates this trend. In professional services, value cocreation revolves around the idea that value is generated during interaction between the service provider and the client (Gronroos \& Voima, 2013). Professional service providers focus on help for the client to cope with internal and external problems, i. e. optimizing business processes, searching a business niche, enhancing employees' competence, improving service quality, etc. Therefore, the service provider cannot obtain an expected result without client input. This input in the form of integration of resources and capabilities becomes increasingly critical. The professional service provider and client collaborate and create the value together. Consulting companies that aim to build trusting relationships, gain unique experiences, produce a mutually valuable outcome and have a competitive edge over rivals. Learning from and with their clients will strengthen the co-creation.

Our research focuses on the processes of value cocreation between a business consulting and couching company as a professional service firm and its clients, and tries to discover what actually happens when value is cocreated through the lens of clients. In relation to the value co-creation processes, terms such creation, interchange, learning, customizing, facilitation, open, assess, help, operate, review, trust were often discussed by participants of the research. They have also clearly identified the resources and capabilities of each side needed for value co-creation.

Focusing on only one party (client) in the service dyad was a conscious decision because the service provider as the initiator of the co-creation has a deeper understanding of the value co-creation processes and methods of how value can be created. The client's perception and interpretation of the value co-creation process is critical for the service provider, in order to improve the collaboration with the client. Participants' answers revealed that the studied business consulting and couching company has invested much effort for creating a co-creative organizational culture.

This research contributes to the body of knowledge on value co-creation by providing empirical evidence on how processes of value co-creation unfold in the context of business consulting and couching services as one of the professional services. Nevertheless, the study has limitations that constitute possible lines of research for the future. Firstly, it is a single case with limited diversity of involved participants. More expansive studies in the business consulting field, as well as other professional service industries, are needed to enrich the knowledge about the variety of value co-creation processes, the roles of provider and client, and the resources and capabilities integrated to co-create the value. These studies should employ both qualitative approaches with larger samples and quantitative methods. Secondly, this study clearly takes the client's perspective, thus, it would be interesting to investigate the value co-creation processes from the service provider's perspective. In addition, focusing on more actors (stakeholders) involved in value co-creation could be meaningful. Despite these limitations, the authors hope that their efforts provide a step forward on the path towards a better understanding of the processes of value co-creation between professional service providers and its clients.

Acknowledgements. The authors wish to thank prof. H. Bouwman for his helpful comments on early drafts of this article. The authors would also like to thank the business companies' executives and employees involved in this research.

\section{References}

Aarikka-Stenroos, L., \& Jaakkola, E. (2012). Value Co-Creation in Knowledge Intensive Business Services: A Dyadic Perspective on the Joint Problem Solving Process. Industrial Marketing Management, 41(1), 15-26. https://doi.org/10.1016/j.indmarman.2011.11.008

Antonova, A. (2012). Service science, value creation, and sustainable development: Understanding service-based business models for sustainable future. In N. Delener (Ed.), Service science research, strategy and innovation: dynamic knowledge management methods: dynamic knowledge management methods (pp. 157-169). Hershey: Business Science Reference. https://doi.org/10.4018/978-1-4666-0077-5.ch010

Baumann, J., Le Meunier-FitzHugh, K., \& Wilson, H. N. (2017). The Challenge of Communicating Reciprocal Value Promises: Buyer-Seller Value Proposition Disparity in Professional Services. Industrial Marketing Management, 64, 107-121.https://doi.org/10.1016/j.indmarman.2017.02.002

Bettencourt, L. (2010). Service innovation: How to go from customer needs to breakthrough services. McGraw Hill Professional.

Bharti, K., Agrawal, R., \& Sharma, V. (2014). What Drives the Customer of World's Largest Market to Participate in 
Value Co-Creation? Marketing Intelligence \& Planning, 32(4), 413-435. https://doi.org/10.1108/MIP-07-2013-0111

Dawson, R. (2012). Developing knowledge-based client relationships. Leadership in professional services. Second edition. Amsterdam: Routledge.

Empson, L., Muzio, D., Broschak, J., \& Hinings, B. (2015). The Oxford handbook of professional service firms. Oxford University Press, Oxford.

Eriksson, P., \& Kovalainen, A. (2015). Qualitative methods in business research. A practical guide to social research. 2nd edition. London: Sage.

Farguhar, J. D. (2012). Case study research for business. London: Sage Publications. https://doi.org/10.413 $5 / 9781446287910$

Fischer, A., Sieg, J. H., Wallin, M. W., \& Krogh, G. V. (2014). What Motivates Professional Service Firm Employees to Nurture Client Dialogues? The Service Industries Journal, 34(5), 399-421. https://doi.org/10.1080/02 642069.2014 .871535

Gallarza, M. G., \& Saura, I. G. (2006). Value Dimensions, Perceived Value, Satisfaction and Loyalty: An Investigation of University Students' Travel Behaviour. Tourism Management, 27(3), 437-452. https://doi.org/10.1016/j.tour man.2004.12.002

Galvagno, M., \& Dalli, D. (2014). Theory of Value Co-Creation: a Systematic Literature Review. Managing Service Quality, 24(6), 643-683. https://doi.org/10.1108/MSQ-09-2013-0187

Gronroos, C. (2011). Value Co-creation in Service Logic: A Critical Analysis. Marketing Theory, 11(3), $279-301$. https://doi.org/10.1177/1470593111408177

Gronroos, C., \& Helle, P. (2010). Adopting a Service Logic in Manufacturing: Conceptual Foundation and Metrics for Mutual Value Creation. Journal of Service Management, 21(5), 564-590. https://doi.org/10.1108/095642 31011079057

Gronroos, C., \& Voima, P. (2013). Critical Service Logic: Making Sense of Value Creation and Co-Creation. Journal of the Academy of Marketing Science, 41(2), 133-150. https://doi.org/10.1007/s11747-012-0308-3

Gummesson, E., \& Mele, C. (2010). Marketing as value Co-Creation through Network Interaction and Resource Integration. Journal of Business Market Management, 4(4), 181-198. https://doi.org/10.1007/s12087-010-0044-2

Gustafsson, S., Swart, J., \& Kinnie, N. (2017). 'They are your testimony': Professionals, Clients and the Creation of Client Capture During Professional Career Progression. Organization Studies, DOI: 0170840617708001.

Hogan, S. J., Soutar, G. N., McColl-Kennedy, J. R., \& Sweeney, J. C. (2011). Reconceptualizing Professional Service Firm Innovation Capability: Scale Development. Industrial Marketing Management, 40(8), 1264-1273. https://doi.org/10.1016/j.indmarman.2011.10.002

Howden, C., \& Pressey, A. D. (2008). Customer Value Creation in Professional Service Relationships: the Case of Credence Goods. The Service Industries Journal, 28(6), 789-812. https://doi.org/10.1080/02642060801990361

Hoyer, W. D., Chandy, R., Dorotic, M., Krafft, M., \& Singh, S. S. (2010). Consumer Cocreation in New Product Development. Journal of Service Research, 13(3), 283-296. https://doi.org/10.1177/1094670510375604

Hsieh, H. F., \& Shannon, S. E. (2005). Three approaches to qualitative content analysis. Qualitative health research, 15(9), 1277-1288. https://doi.org/10.1177/1049732305276687

Jouny-Rivier, E., Reynoso, J., \& Edvardsson, B. (2017). Determinants of Services Co-Creation with Business Customers. Journal of Services Marketing, 31(2), 85-103. https://doi.org/10.1108/JSM-01-2016-0001

Kaiser, S., \& Ringlstetter, M. J. (2011). Strategic management of professional service firms. Theory and practice. Heidelberg: Springer. https://doi.org/10.1007/978-3-642-16063-9

Kipping, M. (2011). Hollow from the Start? Image Professionalism in Management Consulting. Current Sociology, 59(4), 530-550. https://doi.org/10.1177/0011392111402727

Ko, D. G. (2014). The Mediating Role of Knowledge Transfer and the Effects of Client-Consultant Mutual Trust on the Performance of Enterprise Implementation Projects. Information \& Management, 51(5), 541-550. https://doi.org/10.1016/j.im.2014.04.001

Komulainen, H. (2014). The Role of Learning in Value Co-Creation in New Technological B2B Services. Journal of Business \& Industrial Marketing, 29(3), 238-252. https://doi.org/10.1108/JBIM-04-2011-0042

Krueger, R. A., \& Casey, M. A. (2014). Focus groups: a practical guide for applied research. New Delhi: Sage 
Liudmila Bagdoniene, Gintare Valkauskiene. Working Together: Understanding Value Co-Creation Processes in ...

Publications.

Kukk, J., \& Leppiman, A. (2016). Value Creation in Business Services through the Prism of Experience Economy: Conceptualizing Value-in-experience. Journal of Creating Value, 2(2), 231-245. https://doi.org/10.1177/2394964 316643448

Kukk, J., Leppiman, A., \& Pohjola, A. (2015). Designing a Business Service Experience: Customer's Perspective on Value Co-creation. Research in Economics and Business: Central and Eastern Europe, 6(1), 50-64.

Kvale, S. (2009). InterViews. Learning the craft of qualitative research interviewing. Thousand Oaks: Sage Publications.

Liamputtong, P. (2011). Focus group methodology. Principle and practice. London: Sage Publications. https://doi.org/10.4135/9781473957657

Lombardo, S. (2014). Client-Consultant Interaction Practices: Sources of Ingenuity, Value Creation and Strategizing. A dissertation submitted to BI Norwegian Business School for the degree of $\mathrm{PhD}$. Available from internet: https://brage.bibsys.no/xmlui/bitstream/handle/11250/218998/2014-10-

Lombardo_BI\%20Brage\%20version.pdf?sequence=1

Lombardo, S., \& Cabiddu, F. (2017). What's in it for Me? Capital, Value and Co-creation Practices. Industrial Marketing Management, 61, 155-169. https://doi.org/10.1016/j.indmarman.2016.06.005

Longhurst, R. (2003). Semi-structured interviews and focus groups. In N. Clifford, M. Cope, T. Gillespie, S. French (Ed.), Key methods in geography. Third edition. (pp. 117-132). Los Angeles: Sage.

Lowendahl, B. (2005). Strategic management of professional service firms. Copenhagen: Copenhagen Business School Press.

Lush, R. F., Vargo, S. L., \& O'Brien, M. (2007). Competing through Service: Insights from Service-Dominant Logic. Journal of Retailing, 83(1), 5-18. https://doi.org/10.1016/j.jretai.2006.10.002

Madhavaram, S., \& Hunt, S. D. (2017). Customizing Business-To-Business (B2B) Professional Services: the Role of Intellectual Capital and Internal Social Capital. Journal of Business Research, 74, 38-46. https://doi.org/10.10 16/j.jbusres.2017.01.007

Myers, M. (2013). Qualitative research in businesss and management. Second edition. London: Sage.

NACE Rev. 2. Statistical Classification of Economic Activities in the European Community. Luxenbourg: Office for Official Publications of the European Communities, 2008. Available from internet: http://ec.europa.eu/eurostat/docu ments/3859598/5902521/KS-RA-07-015-EN.PDF

Neghina, C., Bloemer, J., van Birgelen, M., \& Caniels, M. C. (2017). Consumer Motives and Willingness to Co-create in Professional and Generic Services. Journal of Service Management, 28(1), 157-181. https://doi.org/10.1108/JOSM12-2015-0404

Ng, I. C. L., Nudurupati, S. S., \& Tasker, P. (2010). Value co-creation in the delivery of outcome-based contracts for business-to-business service. Advanced Institute of Management Research Working Paper. Available from internet: https://ore.exeter.ac.uk/repository/handle/10036/99859 https://doi.org/10.1596/1813-9450-5187

Nikolova, N., Mollering, G., \& Reihlen, M. (2015). Trusting as a 'Leap of Faith': Trust-building Practices in ClientConsultant relationships. Scandinavian Journal of Management, 31(2), 232-245. https://doi.org/10.1016/j.sca man.2014.09.007

Nikolova, N., Reihlen, M., \& Schlapfner, J. F. (2009). Client-Consultant Interaction: Capturing Social Practices of Professional Service Production. Scandinavian Journal of Management, 25(3), 289-298. https://doi.org/10.101 6/j.scaman.2009.05.004

Omachonu, V., Haar, J., \& Berg, D. (2016). Assessing quality in professional services: a framework for gap analysis. International Journal of Transitions and Innovation Systems, 5(1), 4-19. https://doi.org/10.1504/IJTIS.2016.081553

Payne, A. F., Storbacka, K., \& Frow, P. (2008). Managing the Co-creation of Value. Journal of the Academy of Marketing Science, 36(1), 83-96. https://doi.org/10.1007/s11747-007-0070-0

Piligrimiene, Z., Dovaliene, A., \& Virvilaite, R. (2015). Consumer Engagement in Value Co-creation: what Kind of Value it Creates for Company? Inzinerine Ekonomika-Engineering Economics, 26(4), $452-460$. https://doi.org/10.57 55/j01.ee.26.4.12502

Prahalad, C. K., \& Ramaswamy, V. (2004). Co-creating Unique Value with Customers. Strategy \& leadership, 32(3), 49. https://doi.org/10.1108/10878570410699249

Rennie, M. D., Kopp, L. S., \& Lemon, W. M. (2010). Exploring Trust and the Auditor-Client Relationship: Factors 
Influencing the Auditor's Trust of a Client Representative. Auditing: a Journal of Practice \& Theory, 29(1), 279293. https://doi.org/10.2308/aud.2010.29.1.279

Saarijarvi, H., Kannan, P. K., \& Kuusela, H. (2013). Value Co-creation: Theoretical Approaches and Practical Implications. European Business Review, 25(1), 6-19. https://doi.org/10.1108/09555341311287718

Sanchez-Fernandez, R., \& Iniesta-Bonillo, M. A. (2007). The Concept of Perceived Value: A Systematic Review of the Research. Marketing theory, 7(4), 427-451. https://doi.org/10.1177/1470593107083165

Schertzer, S. M. B., Schertzer, C. B., \& Dwyer, R. F. (2013). Value in Professional Service Relationships. Journal of Business \& Industrial Marketing, 28(8), 607-619. https://doi.org/10.1108/JBIM-03-2011-0028

Seiders, K., Flynn, A. G., Berry, L. L., \& Haws, K. L. (2015). Motivating Customers to Adhere to Expert Advice in Professional Services: a Medical Service Context. Journal of Service Research, 18(1), 39-58. https://doi.org/10.117 $7 / 1094670514539567$

Sjodin, D. R., Parida, V., \& Wincent, J. (2016). Value Co-creation process of Integrated Product-Services: Effect of Role Ambiguities and Relational Coping Strategies. Industrial Marketing Management, 56, $108-119$. https://doi.org/10.10 16/j.indmarman.2016.03.013

Sonmez, M., \& Moorhouse, A. (2010). Purchasing Professional Services: Which Decision Criteria? Management Decision, 48(2), 189-206. https://doi.org/10.1108/00251741011022572

Stenroos, L. A., \& Jaakkola, E. (2010). Value Co-creation within Buyer-Seller Relationships in Knowledge-Intensive Business Services. In Competitive paper accepted for the IMP2010 conference, Budapest, Hungary. Available from internet: https://pdfs.semanticscholar.org/5d11/e5ae9bf0f0878109ff29ccf61a10dd256dd2.pdf

Steward, D. W., \& Shandasani, P. N. (2015). Focus group. Theory and practice. Third edition. Thousands Oaks: Sage Publications.

Taminiau, Y., Ferguson, J., \& Moser, C. (2016). Instrumental Client Relationship Development among Top-Ranking Service Professionals. The Service Industries Journal, 36(15/16), 789-808. https://doi.org/10.1080/02642069.20 16.1272589

Teddlie, C., \& Yu, F. (2007). Mixed Methods Sampling: A Typology with Examples. Journal of Mixed Methods Research, 1(1), 77-100. https://doi.org/10.1177/2345678906292430

Trischler, J., Pervan, S., \& Scott, D. R. (2017). Exploring the 'Black Box'of Customer Co-Creation Processes. Journal of Services Marketing, 31(3), 265-280. https://doi.org/10.1108/JSM-03-2016-0120

Urbonavicius, S., \& Dikcius, V. (2005). Specifics of Business Consulting Services Used by Small and Medium Enterprises in a Transition Economy. Inzinerine Ekonomika-Engineering Economics, 43(3), 74-80.

Verschuren, P., Doorewaard, H., \& Mellion, M. (2010). Designing a research project. Second edition. Hague: Eleven International Publishing.

Von Nordenflycht, A. (2010). What is a Professional Service Firm? Toward a Theory and Taxonomy of KnowledgeIntensive Firms. Academy of management Review, 35(1), 155-174. https://doi.org/10.5465/AMR.2010.45577926

Zhang, X., \& Chen, R. (2008). Examining the Mechanism of the Value Co-creation with Customer. International Journal of Production Economics, 116, 242-250. https://doi.org/10.1016/j.ijpe.2008.09.004

Zieba, M., \& Zieba, K. (2014). Knowledge Management Critical Success Factors and the Innovativeness of KIBS companies. Inzinerine Ekonomika-Engineering Economics, 25(4). 458-465. https://doi.org/10.5755/j01.ee.25.4.6494

Zwass, V. (2010). Co-creation: Toward a Taxonomy and an Integrated Research Perspective. International Journal of Electronic Commerce, 15(1), 11-48. https://doi.org/10.2753/JEC1086-4415150101

The article has been reviewed.

Received in June, 2017; accepted in February, 2018. 